\title{
INFLUENCE OF COMPANY VALUE INFORMATION, DIVIDEND POLICY, AND CAPITAL STRUCTURE ON STOCK PRICE
}

\author{
Rita Syofyan¹, Defriko Gusma Putra², Riyadi Aprayuda³ \\ ${ }^{1}$ Faculty of Economics, Universitas Negeri Padang,West Sumatra, Indonesia \\ ${ }^{2}$ Faculty of Economics, Universitas Andalas, West Sumatra, Indonesia \\ ${ }^{3}$ Faculty of Economics and Business, Universitas Muhammadiyah Riau,Riau, Indonesia \\ *Email Corresponding Author: ritasyofyanunp@gmail.com
}

\begin{abstract}
This study aims to examine the effect of firm value, dividend policy, and capital structure on stock prices. Specifically, firm value is measured by Price-Book Value (PBV), dividends are measured by the Dividend Payout Ratio (DPR), the capital structure in this study is measured based on the Equity Ratio (DER), and stock prices are measured based on cumulative abnormal returns. This study uses secondary data from 43 manufacturing companies listed on Indonesia Stock Exchange. Data were analyzed using multiple linear regression. The results showed that dividend policy has a positive effect on stock prices, and capital structure has a negative effect on stock prices. However, the firm value does not affect stock prices. This finding underlines that the large value of the company reflected by the PBV will indicate an expensive stock price so that investors have not fully taken into account the share purchase. As a practical contribution, manufacturing companies can apply dividend distribution incorporates actions periodically to increase the value of the company's shares. Besides, manufacturing companies can reduce the capital structure policy using debt because it will reduce the value of the company's shares.
\end{abstract}

Keywords: Company Value, Dividend Policy, Capital Structure, Stock Price, Stock Market

\section{INTRODUCTION}

One of the indicators driving the economy is the stock market, a model market that reflects the business activities of a country so that the company's business activities are reflected in the stock market. Shares purchased by investors from trading on the capital market come from companies that sell their ownership so that if investors buy their shares, they get funds to carry out business expansion activities and realize efforts to improve performance. Therefore, if the businesses in a country can develop their business, it will directly improve the economy. Thus companies must reflect positive business activities in their financial reports, because from the order of financial information produced by the company, investors will make a decision to invest in the company (Aprayuda et al., 2021; Softyan et al., 2020), and the information provided is generated will generate their interest and interest to find out more about the company (Aprayuda and Misra, 2020). Husnan (2008) reveals that there are several attractions in the capital market to improve the economy. First, it can be an alternative to the banking sector in raising funds and can provide choices to investors according to their respective preferences.

Capital market efficiency is an indicator to determine the quality of a capital market. According to Husnan (2008), Market efficiency is where the price on the stock or the movement of its size has shown all market information so that no investor gets an abnormal return. The 
sooner new information appears on the price of a security, the more efficient the capital market will be. The efficient market theory is based on the assumption that all market participants process information rationally and on average the information held by market participants is correct (Putra, 2012). When the stock market is in an efficient condition, market conditions will reflect all information, so this condition makes stock price fluctuations very significant because the sensitivity of the information is fully reflected.

As a reference in investing, investors use facilities in the form of financial reports issued by the company. The financial report is information on how the company's performance conditions in a certain period. (Putra and Rahayu, 2020). Financial reports are a means of information for users in the decision-making process so that by using the information obtained from the financial reports, investors can assess the investment they are making with the level of returns and risks they will face. According to Putra et al (2021), financial statements are useful for investors to determine the best and most profitable investment decisions. By analyzing financial statement information, investors can see a comparison between the intrinsic value of a stock and its market price. Based on this comparison, investors can decide whether to buy or sell stocks.

Regarding the level of profit and risk in investing, investors can choose various investments that can be made, one of which is in the form of stocks. Stocks are proof of ownership of the assets of companies that issue stocks (Tandelilin, 2001). Changes in stock prices that occur in the capital market are related to investors' reactions to the various information they receive. So, investors' reactions are the market's response to changes in confidence from information released by the company, such as company performance information, earnings information, dividend policy, use of debit, and other fundamental information related to the company.

Some investors are rational, that is, they view the company's performance (fundamental analysis) as a reference in analyzing stock prices. Fundamental analysis can describe the prospects of a company (Syofyan and Putra, 2020). Companies with better prospects are more attractive to investors because they are considered capable of providing stable profits, and will affect the company's stock price. Besides being able to see the company's prospects, fundamental analysis can also be used to assess the company's risk, because most investors tend to be risk-averse, that is, stay away from risk (Tandelilin, 2001).

Investors will not want to invest in companies with bad prospects or companies that are high risk due to heavy debt. So, in every investment between prospect and risk, there will always be company prospects that can be seen from the company value (Sofyan et al., 2020). The value of the company that the prospective buyer of the company is willing to pay is sold (Husnan, 2008). From this understanding, it can be seen that company value reflects the abstraction of that performance. Good or bad the company will affect the reaction of investors to the investment they choose.

Sartono (2001) states that the dividend distribution policy is stipulated in the GMS, dividends are generated from profits and distributed to shareholders. The remainder of the profit-sharing is retained earnings for the company. Dividends are the main trigger for investors to invest because the higher the dividend rate to be distributed, the more prosperous the investors will be. Therefore, dividend policy reflects the realization of the benefits that will be obtained by shareholders. One of the ratios that shows the percentage level of dividends distributed by the company is the Dividend Payout Ratio (DPR).

According to Tandelilin (2001), the Dividend Payout Ratio (DPR) shows the number of dividends the company will payout of the total profit the company receives. Therefore, it should be noted that an increase in the percentage of profits paid as dividends can provide a positive signal for investors. Most investors view dividend payout policies as a prospect for the company. For example, when a company increases the percentage of dividends that will be paid, this can be interpreted that management estimates that the company's prospects will improve in the 
future and will affect the company's stock price.

About risk, the capital structure or debt policy is one of the risks from the investor's point of view. Due to the nature of risk-averse investors, they tend to stay away from risk (Tandelilin, 2001). Sartono (2001) states that capital structure is a company's policy in determining whether the company borrows money to make long-term debt or short-term debt, or makes policies to issue company shares or sell part of the ownership of the company to investors. This division of the capital structure is important to illustrate how companies use debt policies or issue shares. It also describes the risks the company has. Companies with a capital structure that is filled with debt tend to be shunned by investors, because high debt is a burden that will be borne from the investment, besides that companies with high debt also have a high risk of liquidation or an inability to pay off all their obligations. From this condition, investors will react negatively to the high value of the capital structure and will affect the company's stock price.

Previous research has found different findings, including the Price to Book Value (PBV) variable which was researched by Anah, Firdaus and Alliffah (2018) which results have a positive effect on the stock price studied by Jumhana (2016) Price to Book Value (PBV) does not affect stock prices and research conducted by Beliani and Budiantara (2015) in their research shows that the Price to Book Value (PBV) variable has a positive and insignificant effect on stock prices. The Dividend Payout Ratio (DPR) variable researched by Chaudry, Iqbal and Butt (2015) has a significant effect on stock prices, while the one researched by Bailia, Tommy and Baramulli (2016) does not affect stock prices. This difference also occurs in the Debt to Equity Ratio (DER) variable studied by Menon (2016) which has a significant negative effect on stock prices and the research of Anah, Firdaus and Alliffah (2018) has a negative but insignificant effect on stock prices. Meanwhile, research by Suryawan and Wirajaya (2017) obtained results that do not affect stock prices.

This research is interesting to do because the development of the capital market in Indonesia leads to an efficient direction in which all relevant information can be used as an input to evaluate. Share prices and the tendency of investors to reject risk (risk-averse) so that this aspect of information can be used as a basis for decision making. Then, the company's fundamental financial indicators are often used as a reference in making stock investment decisions before deciding to buy shares in a company, investors need a variety of information to be analyzed to make the right decision.

This study shows that dividend policy has a positive effect on stock prices, and capital structure has a negative effect on stock prices. However, the firm value does not affect share prices. This finding underlines that the size of the company as reflected in the PBV will indicate an expensive stock price so that investors have not fully taken into account the purchase of these shares. With the manufacturing company selected in this study, so that as a form of practical contribution, the manufacturing company can implement periodic dividend distribution measures to increase the value of the company's shares. Besides, manufacturing companies can reduce the capital structure policy by using debt because it will reduce the value of the company's shares.

\section{LITERATURE REVIEW AND HYPOTHESIS DEVELOPMENT}

\section{Efficient Market Theory}

Efficient market theory relies on the assumption that all market participants process information rationally and that on average the information held by all market participants is correct. Husnan (2005) states that efficient market forms are grouped into three, namely:

Weak form efficient market

In these circumstances, the stock price reflects all information contained in the past. In this 
situation, the investor cannot obtain an above-normal level of return based on past information. Semi strong form efficient market

In this situation, the stock price not only reflects past prices, but all information is published. In other words, investors cannot obtain a profit level above normal by utilizing public information. Research on the issuance of new stocks, announcements of earnings and dividends, estimates of company earnings, etc., generally shows that this information is quickly and accurately reflected in the stock price.

Strong form efficient market

In this situation, the stock price not only reflects all published information but also information that can be obtained from a fundamental analysis of the company and the economy. In this situation, the price is always reasonable and no investor can get a better estimate of the stock price.

Stock

One type of investment that is quite attractive to the public is investing in stocks. Shares are proof of ownership of the assets of the company that issued shares. Tandelilin (2001) states that shares are evidence or a sign of ownership of assets or part of the capital in a company that issues shares. The advantages of buying shares according to Tandelillin (2001) are as follows:

Dividend

The profit-sharing given by the company per share is based on the profits generated by the company, where dividends are given after obtaining approval from the shareholders.

Capital Gains

It is the difference between the purchase price and the selling price, where the selling price of the shares must be higher than the purchase price of the shares.

Bonus Shares

Is a share that is the company's shares to shareholders taken from the additional paid-in capital.

Share premium

This is the difference between the selling price and the nominal price when the company makes a public offering on the primary market.

\section{Stock Prices}

An efficient capital market price is formed through the supply and demand mechanism in the capital market. Stock prices change up to or down from one time to another (Sartono, 2001). Changes in share prices that occur in the capital market are related to investors' reactions to various information they receive. So, the reaction of investors is a market response to changes in confidence from information issued by the company, such as company performance information, earnings information, dividend policy, debit use, and other fundamental information relating to the company. Conversely, if there is an excess supply, the stock price tends to fall. Changes in stock prices that occur in the capital market are related to investors' reactions to the various information they receive. So, investors' reactions are the market's response to changes in confidence from information released by the company, such as company performance information, earnings information, dividend policy, use of debit, and other fundamental information related to the company.

Stock prices are measured by abnormal returns. An abnormal return is an abnormal return that is shown by the difference between realization return and expected return. Realized return is the return expected by investors, while the advantage or disadvantage of the expected return is the abnormal return. The measurement of expected return to calculate the abnormal return in this study uses a market-adjusted model. In Jogiyanto (2007) Here is the formula for calculating the abnormal return: 


$$
\begin{gathered}
R i t=\frac{P_{i t}-P_{i t-1}}{P_{i t-1}} \\
R m t=\frac{I H S G_{m t}-I H S G_{m t-1}}{I H S G_{m t-1}} \\
A R i t=R i t-R m t
\end{gathered}
$$

In this :

ARit: Abnormal return for the company i on day $t$

Rit: Daily return of company i on day $t$

Rmt: The market index returns on the t-day

Pit: The index of the individual stock price of the company $i$ at time $t$

Pit-1: The individual stock price index of the company i at time t-1

IHSGmt: Composite Stock Price Index at time t

IHSGmt-1: Composite Stock Price Index at time t-1.

The window period used to calculate the abnormal return is 7 days involving 3 days before and 3 days after and 1 day at the time of publication of the financial statements of each company. Jogiyanto (2007) states that the length of commonly used windows ranges from 3 days to 121 days for daily data. The reason for using the 7-day window period in this study is that the information obtained is newer and can be directly absorbed by investors. The window period involves the period before the publication of the financial statements because the window period involving the days before the event is used to determine whether information leakage has occurred. Investors are thought to have known the company's performance through other media before the publication of the financial statements (Jogiyanto, 2007).

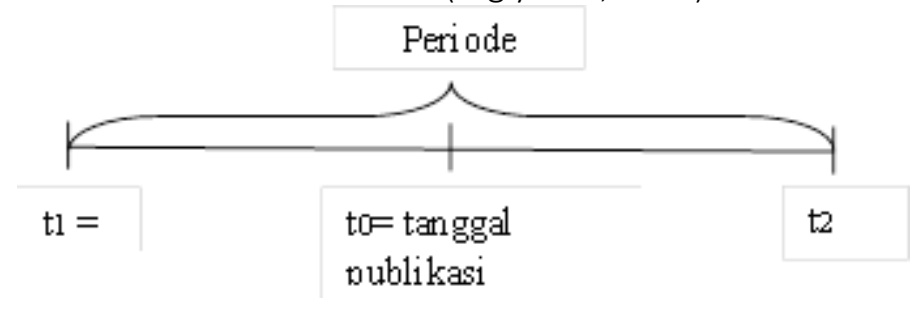

Picture 1

Observation Period for Abnormal Return

To be able to test the abnormal return value at the stock price, AR is accumulated to become CAR (cumulative abnormal return). The calculation of CAR (cumulative abnormal return) for each company is the accumulation of the average abnormal return for the 7-day window period ending in $\mathrm{t} 2$, using the following formula:

$$
\text { CAR it }=\sum_{a=t 3} \quad A R i, a
$$

In this:

CAR it: Cumulative Abnormal Return of company i at time $t$

\section{Company Value}

The main objectives of the company in carrying out its operations can be divided into two, namely: short-term goals in the form of efforts to obtain maximum profit, and long-term goals to maximize shareholder wealth. This provides guidance to managers to maximize the value of the 
company as seen from its stock price. The higher the company value, the higher the stock value. Company value is created by the company through company activities from time to time to achieve maximum company value above book value. The company value is the price a prospective buyer is willing to pay if the company is sold (Husnan, 2008: Husni et al., 2020). From this understanding, it can be seen that the company's value reflects the abstraction of the company's performance whether the company is good or bad and this will affect the reaction of investors to their chosen investment. So that from these conditions investors will have an interest in the analysis of company value because the analysis of company value will provide useful information to investors in assessing the prospects of the company in the future in generating profits. Thus, companies that have good corporate values will provide a positive signal for rising stock prices. Company value is a variable that cannot be observed, therefore company value requires a proxy. According to Sari (2010) values can be identified in proxies, namely:

Price based proxies

The variables used to measure company value in price-based proxies are Market to Book Value Asset (MBVA), Market to Book Value Equity (MBVE), Price to Book Value (PBV), Price Earning Ratio (PER), and Tobin's Q.

Market to Book Value Asset (MBVA)

With the premise that MBVA reflects the market rate of future investment returns to be more than the expected return on equity. This MBVA assumes that the company's growth will be high if it has a market value or price that is much greater than its book value.

MBVA = Total assets-total equity (number of shares outstanding $\mathrm{x}$ price) / Total equity Market to Book Value Equity (MBVE)

With the premise that the company's growth prospects are reflected in the stock price, the market values the company to be greater than its book value. MBVE measures the present value of all future cash flows to owners of equity. A high MBVE will increase the company's growth opportunities.

Price to Book Value (PBV)

MBVE = Number of shares outstanding $x$ price / Total Equity

Is a comparison between the share price and the book value of shares per share. Based on this comparison, it can be seen whether the share price is above or below the book value of the company's shares.

$$
\mathrm{PBV}=\text { Stock price } / \text { book value per share }
$$

Price Earning Ratio (PER)

With the premise that the value of equity is the sum of the value of capitalization of earnings and asset management plus net present value (NPV) of future investment choices, so that the smaller the Price Earning Ratio (PER) the greater the proportion of equity value that is distributed to the profit generated by relative assets. opportunity to grow. PER according to Koetin (2002) is a comparison between stock prices. PER can be used to determine whether the stock price is expensive and has a low risk or vice versa, a low stock price with a high level of risk.

$$
\text { PER = Stock Price / EPS }
$$

Company value in this study is measured by Price to Book Value (PBV). Price to Book Value (PBV) is the ratio between the market price of a stock and its book value. The Price to Book Value (PBV) ratio can be expressed by the following formula:

PBV = stock price / Book value per share (BVS)

Source: K.R. Subramanyam and Jhon J. Wild (2010)

BVS = Total Capital / Number of Outstanding Shares 
Source: Jogiyanto (2003)

A high Price to Book Value (PBV) will make the market believe in the company's financial prospects (Darmadji and Fakhrudin, 2001). So, the greater the Price to Book Value (PBV) ratio, the more investors will be interested in the stock. Thus, performing a Price to Book Value (PBV) analysis will affect stock prices. According to Tandelilin (2001) stocks that have a high PBV will tend to have a higher return rate compared to stocks that have a low PBV.

\section{Dividend Policy}

Dividend policy concerns decisions to distribute profits or hold them to be reinvested in the company. Dividend stability over time. Brigham and Houston (2001) there are several dividend policy theories, including Irrelevant Dividends, Bird In-the Hand Theory, that is the cost of own capital (Ks) will increase if the DPR is low because investors prefer to receive dividends rather than capital gains. Investors view dividend yield (D1 / P0) as more certain than capital gains yield (g). So, companies that adhere to this concept must distribute the entire EAT in the form of dividends, Tax Differential Theory (tax Differential Theory), Signaling Hypothesis Theory that is An increase in dividends is a signal that the company is forecasting a good income in the future, and vice versa. Hypothesis signaling theory is the theory that investors perceive changes in dividends as a harbinger of management or earnings forecasts, and Clientele Effect Theory this theory states that different shareholders will have different preferences for the company's dividend policy, so according to this theory, dividends should be aimed at meeting the needs of certain segments of investors. Groups of investors with a high tax rate will avoid dividends because dividends have a higher tax rate than capital gains. Besides, capital gains can also delay tax payments. Conversely, a group of investors with low taxes will like dividends. Dividend payments are part of the company's dividend policy, the dividend payout ratio can be calculated as follows:

$$
D P R=D P S / E P S
$$

Source: Tandelilin (2001)

\section{Capital Structure}

Capital structure or debt policy is one of the risks from an investor's point of view. This is due to the nature of risk-averse investors, that is, they tend to stay away from risk (Tandelilin, 2001). Analysis of the capital structure is important for investors because it can provide information about the risks the company has. Companies with capital structures that are filled with debt tend to be shunned by investors, because high debt is a burden that will be borne from their investment, besides that companies with high debt also have a high risk of liquidation or an inability to pay off all of their obligations. From this condition, investors will react negatively to the high value of the capital structure and will affect the company's stock price. According to Sartono (2001), there are several ratios in measuring capital structure, namely:

Debt Ratio (DR)

This ratio measures how much assets are financed by debt. The higher this ratio, the greater the risk faced, and investors will ask for a higher rate of return.

$$
\text { Debt ratio }=\text { Total Liabilities } / \text { Total Assets }
$$

\section{Debt to Equity Ratio (DER)}

The debt to equity ratio is a ratio that shows the ratio between debt provided by creditors and the amount of equity provided by the owner of the company (Husnan, 2005). This ratio shows the proportion of the use of debt compared to own capital to finance investment. 
Debt to equity ratio $=$ Total Debt $/$ Total Own Equity

Time Interest Ratio (TIR)

Time interest ratio is a ratio that measures the company's ability to meet its fixed expenses in the form of interest, or measures how far profits can be reduced without the company experiencing financial difficulties because it is unable to pay interest.

Time interest ratio $=$ Earnings Before Interest and Taxes $/$ Interest Expenses

In this research, capital structure is measured by the Debt to Equity Ratio (DER). Debt to Equity Ratio (DER) is used to measure the level of use of debt against the company's capital and is formulated as follows:

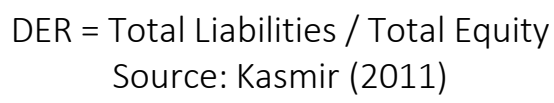

Debt to Equity Ratio (DER) is the proportion of debt to equity used in carrying out company operations. The greater the Debt to Equity Ratio (DER) reflects the relatively high risk of the company and the greater the risk borne by investors. A rational investor would certainly not like uncertainty or risk. Investors like this will not want to take the risk of an investment if the investment does not provide a reasonable rate of return. Investors will avoid buying company stocks so that which will cause a company's stock price to fall (Wahid, 2007).

Hypothesis

Influence of company value on stock prices

Company value is the price a prospective buyer is willing to pay if the company is sold (Husnan, 2008). From this understanding, it can be seen that company value reflects the abstraction of company performance. Whether the company is a good or bad value and will affect the reaction of investors to the investment they choose. Investors will have an interest in company value analysis because company value analysis will provide useful information to investors in assessing the company's prospects in generating profits. Thus, companies that have a good value will give a positive signal and affect rising stock prices.

Several studies have revealed the relationship between company value and stock prices, such as in the research of Beliana and Budiantara (2015) which examined the effect of company value as measured by price book value on stock prices, showing a positive and significant effect. Similar results were also obtained by Anah, Firdaus and Alliffah (2018) in their research that obtained positive results between company value and stock prices. Based on this description, the following hypothesis can be concluded :

H1: company value has a significant positive effect on stock prices.

Influence of dividend policy on stock prices

According to Sari (2010) dividend announcements contain information that results in stock price reactions. Dividend distribution gives a positive signal to investors about the prospect of stocks because it indicates the company's ability to generate profits. Apriani (2005) in her research also concluded that the market reacts strongly to announcements of dividend 
increases/decreases by public utilities. This is indicated by the difference in stock prices before and after the announcement of the increase/decrease in dividends. So, most investors see the policy in dividend payments as a company's prospects, for example, when the company increases the percentage of dividends to be paid, this can be interpreted that management estimates that the company's prospects will improve in the future, thus affecting stock prices.

Several studies have revealed the relationship between dividend policy and stock prices, as in Chaudry, Iqbal and Butt's (2015) study which examined the effect of dividend policy as measured by dividend payout ratio on stock prices with positive and significant results. Similar results were also obtained by Nugraha and Sudaryanto (2016) in their research which obtained positive and significant results between the effect of dividend policy on stock prices. Based on this description, the following hypothesis can be concluded:

H2: Dividend policy has a significant positive effect on stock prices.

Influence of capital structure on stock prices

The nature of investors is risk-averse, which tends to stay away from risk (Tandelilin, 2001). Investors will react negatively to the high value of the capital structure because high debt is a burden that will be borne from their investment, besides that companies with high debt also have a high risk of liquidation or the inability to pay off all of their obligations. Wahid's research (2007) also explains that investors will not want to take the risk of an investment if the investment does not provide a reasonable rate of return. Investors will avoid buying company shares so that which will cause a company's share price to fall.

Several studies have revealed the relationship between capital structure and stock prices, as in Menon's study (2016) which examined the effect of capital structure as measured by debt equity ratio on stock prices with negative and significant results. Similar results were also obtained by Anah, Firdaus and Alliffah (2018) in their research that obtained negative results between the effect of capital structure on stock prices. Based on this description, the following hypothesis can be concluded :

H3: Capital structure has a significant negative effect on stock prices.

\section{RESEARCH METHOD}

The quantitative approach used in this research is causal analysis. The sample selection is done by using purposive sampling technique, namely the selection of samples based on certain criteria. The criteria to be used are:

Manufacturing companies on the IDX listed in 2008-2010 are in the manufacturing industry group and were not delisted from the Indonesia Stock Exchange during the 2008-2010 observation period.

Sample companies publish complete financial reports. The years 2008 to 2010 were chosen because this year is after the recovery of the economic crisis that occurred in 2008, so this period is interesting to be able to describe stock performance based on company value, dividend policy, and capital structure which is also a strategy in business recovery for the raw material processing industry. and trades such as manufacturing companies. This year of observation is also used by Pratama \& Erawati (2014), and Pandansari (2012) in observing the stock performance of manufacturing companies in the capital market.

The sample companies made cash dividend payments during the 2008-2010 observation year. The availability of historical price information for the window period of the sample companies on the Indonesia Stock Exchange during the 2008-2010 observation period. 
Based on the above criteria, the sample of this study was manufacturing companies that were registered on the IDX in 2008 and still registered until 2010 as many as 158 companies, but 8 companies were delisted and no longer listed on the IDX. 22 companies do not publish complete financial reports, and 74 companies never pay dividends during the year of observation, and 11 companies do not have historical prices available in the window period. So the companies that will be sampled in this study totaled 43 companies during the observation year, namely from 2008 to 2010. The type of data used in this study is documentary data obtained from manufacturing companies listed on the IDX for the 2008-2010 period. The data source is secondary data and the authors use documentation techniques from data published by manufacturing companies listed on the Indonesia Stock Exchange through the IDX official website: www. IDX. co. id and IDX Statistics Book, Indonesian Capital Market Directory Book, www. yahoo-finance. com and by studying the literature related to research problems in both print and electronic media.

Measurement of Variables

Dependent Variable $(\mathrm{Y})$

Stock prices are measured by abnormal returns. An abnormal return is an abnormal return that is shown by the difference between realization return and expected return. Realized return is the return expected by investors, while the advantage or disadvantage of the expected return is the abnormal return. The measurement of expected return to calculate the abnormal return in this study uses a market-adjusted model. In Jogiyanto (2007), the market-adjusted model assumes that the best measurement of the company's stock expected return is the market index return. Here is the formula for calculating the abnormal return:

$$
\begin{gathered}
R i t=\frac{P_{i t}-P_{i t-1}}{P_{i t-1}} \\
R m t=\frac{I H S G_{m t}-I H S G_{m t-1}}{I H S G_{m t-1}} \\
\text { ARit }=\text { Rit }- \text { Rmt }
\end{gathered}
$$

In this :

ARit: Abnormal return for company i on day $t$

Rit: Daily return of company $i$ on day $t$

Rmt: The market index returns on the t-day

Pit: The index of the individual stock price of company $i$ at time $t$

Pit-1: The individual stock price index of company $i$ at time $t-1$

IHSGmt: Composite Stock Price Index at time t

IHSGmt-1: Composite Stock Price Index at time t-1.

The window period used to calculate the abnormal return is 7 days involving 3 days before and 3 days after and 1 day at the time of publication of the financial statements of each company. Jogiyanto (2007) states that the length of commonly used windows ranges from 3 days to 121 days for daily data. The reason for using the 7-day window period in this study is that the information obtained is newer and can be directly absorbed by investors. The window period involves the period before the publication of the financial statements because the window period involving the days before the event is used to determine whether information leakage has occurred. Investors are thought to have known the company's performance through other media 
prior to the publication of the financial statements (Jogiyanto, 2007).

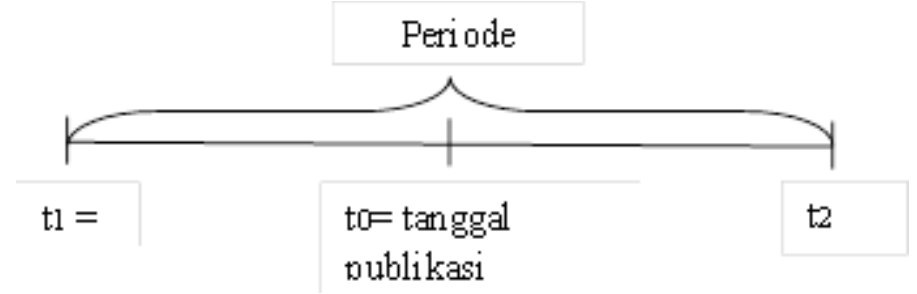

Picture 1

Observation Period for Abnormal Return

To be able to test the abnormal return value at the stock price, $A R$ is accumulated to become CAR (cumulative abnormal return). The calculation of CAR (cumulative abnormal return) for each company is the accumulation of the average abnormal return for the 7-day window period ending in $\mathrm{t} 2$, using the following formula:

$$
\text { CAR it }=\sum_{a=t 3} \quad \text { AR } i, a
$$

In this:

CAR it: Cumulative Abnormal Return of company i at time $t$

Independent Variables $(X)$

Company value in this study is measured by Price to Book Value (PBV). Price to Book Value (PBV) is the ratio between the market price of a stock and its book value. The Price to Book Value (PBV) ratio can be expressed by the following formula:

$$
\mathrm{PBV}=\text { stock price / Book value per share (BVS) }
$$

Source: K.R. Subramanyam and Jhon J. Wild (2010)

BVS = Total Capital / Number of Outstanding Shares

Source: Jogiyanto (2003)

In this research, dividend policy is measured by dividend payout ratio can be calculated as follows:

$$
\begin{gathered}
\text { DPR }=\text { DPS / EPS } \\
\text { Source: Tandelilin (2001) }
\end{gathered}
$$

In this research, capital structure is measured by Debt to Equity Ratio (DER). Debt to Equity Ratio (DER) is used to measure the level of use of debt against the company's own capital and is formulated as follows:

$$
\begin{aligned}
\text { DER = } & \text { Total Liabilities / Total Equity } \\
& \text { Source: } \text { Kasmir (2011) }
\end{aligned}
$$

\section{DISCUSSION RESULTS}

\begin{tabular}{|c|c|c|c|c|c|}
\hline & $\mathrm{N}$ & Minimum & Maximum & Mean & Std. Deviation \\
\hline $\begin{array}{l}\text { Cumulative Abnormal } \\
\text { Return }\end{array}$ & 129 & -.5333 & .4538 & .019451 & .1207506 \\
\hline
\end{tabular}

\section{Descriptive statistics}

Descriptive statistics show an overview of the minimum value, maximum value, total average value and standard deviation of the data used in this study. The research descriptive statistics can be seen in Table 1.

Table 1. Descriptive statistics table 


\begin{tabular}{lllccc} 
Price Book Value & 129 & .1000 & 35.4500 & $2.637752 \mathrm{EO}$ & 4.9265180 \\
Dividend Payout Ratio & 129 & .0000 & 3.0290 & .314217 & .4119246 \\
Debt Equity Ratio & 129 & .0100 & 8.4410 & $1.137674 \mathrm{EO}$ & 1.1962491 \\
\hline
\end{tabular}

Source: Processed secondary data, 2021

Based on the table above, it explains descriptively the variables in this study. The variable stock price (CAR) that occurs in manufacturing companies on average is 0.019451 with a standard deviation of 0.1207506. The highest share price was PT Duta Pertiwi Nusantara Tbk (DPNS) which amounted to 0.5438 and the lowest was PT Darya-Varia Laboratoria Tbk (DVLA) which amounted to -0.5333 . The company value variable (PBV) that occurs in manufacturing companies is an average of 2,637752EO with a standard deviation of 4,9265180. The highest company value is PT Multi Bintang Indonesia Tbk (MLBI), which is 35.4500 and the lowest is PT Intanwijaya International Tbk (INCI), which is 0.100 .

In the dividend policy variable (DPR) that occurs in manufacturing companies, the average is 0.314217 with a standard deviation of 0.4119246 . The highest dividend policy is PT Goodyear Indonesia Tbk (GDYR), which is 3.0290 and the lowest is PT Arwana Citra Mulia Tbk (ARNA) and several other companies with 0.0000. In the capital structure variable (DER) that occurs in manufacturing companies, the average is 1.137605E0 with a standard deviation of 1.1963157. The highest capital structure is PT Multi Bintang Indonesia Tbk (MLBI) which is 8,4410 and the lowest is PT Indocement Tunggal Prakarsa Tbk, which is 0.0100 .

Normality test

This research was conducted using a one-sample Kolmogorov-Smirnov test, where if the asymp.sig (2-tailed) value> 0.05 , the data distribution is said to be normal. In detail, the results of the normality test can be seen in the table below:

Table 2.Kolmogorov Smirnov Test (K-S)

One-Sample Kolmogorov-Smirnov Test

Unstandardized Residual

N

Normal Parameters

Most Extreme Differences
83

Mean

Std. Deviation

Absolute

Positive

Negative

1.052
.218

Kolmogorov-Smirnov Z

Asymp. Sig. (2-tailed)

Source: Processed secondary data, 2021

Based on the table above, it can be seen that the results of the normality test show a significant level greater than $\alpha(\alpha=0.05)$, namely $0.218>0.05$, which means that the data is normally distributed. This means that now the form of the regression equation is in logarithmic form.

\section{Multicollinearity Test}

The multicollinearity test is characterized by a strong relationship between the independent variables in a regression equation. A regression model is declared free of multicollinearity if the VIF value is $<10$ and the tolerance value $>0.10$. The results of the multicollinearity assumption test for this research variable can be seen based on the VIF value and tolerance value as follows: 
Table 3. Multicollinearity test

\begin{tabular}{lcl}
\hline Model & Collinearity Statistics & \\
\hline \multirow{3}{*}{1} & Tolerance & VIF \\
& LN_PBV & .907 \\
& LN_DER & .998 \\
& LN_DPR & .906 \\
\hline
\end{tabular}

Source: Processed secondary data, 202

Based on the table above, the results of the calculation of the VIF value and tolerance can be seen. The VIF value for the company value variable (PBV) is 1.102 with a tolerance of 0.907, dividend policy (DPR) is 1.104 with a tolerance of 0.906 , and capital structure (DER) is 1.002 with a tolerance of 0.998 . Each of these independent variables has a VIF value $<10$ and a tolerance value $>0.1$, so it can be concluded that there are no symptoms of multicollinearity between the independent variables.

Heteroscedasticity test

Heteroscedasticity is used to test whether in a regression model there is an inequality of the residual variance from one observation to another. The results of the heteroscedasticity test are as follows:

Table 4. Heteroskedastisitas (uji Glejser)

\begin{tabular}{|c|c|c|c|c|c|}
\hline \multirow{2}{*}{$\begin{array}{l}\text { Unstandardized Coefficients } \\
\text { Model }\end{array}$} & \multicolumn{2}{|c|}{ Unstandardized Coefficients } & \multirow{2}{*}{$\begin{array}{l}\text { Standardized } \\
\text { Coefficients } \\
\text { Beta }\end{array}$} & \multirow[t]{2}{*}{$\mathrm{t}$} & \multirow[t]{2}{*}{ Sig. } \\
\hline & B & Std. Error & & & \\
\hline \multirow{4}{*}{1} & (Constant) & .052 & .011 & & 0.006 \\
\hline & LN_PBV & -.010 & .006 & -.211 & 0.089 \\
\hline & LN_DER & .007 & .005 & .133 & 0.189 \\
\hline & $L N^{-} D P R$ & -.003 & .007 & -.048 & 0.082 \\
\hline
\end{tabular}

Source: Processed secondary data, 2021

Based on table 4 above, it can be seen that the calculation results of each variable show that the level of sig> 0.05 is $0.068>0.05$ for the company value variable (PBV), $0.676>0.05$ for the dividend policy variable (DPR), and 0.224. $>0.05$ for the capital structure variable (DER). So that this study is free from heteroscedasticity symptoms and is worth investigating.

\section{Autocorrelation Test}

Based on the autocorrelation test, it was found that the Durbin-Watson value of 1.819 was in the range of 1.55. - 2.46 which means that the variable is free from autocorrelation. The test results can be seen in the table below:

Table 5. Autocorrelation Test

\begin{tabular}{lc}
\hline Model & Durbin-Watson \\
\hline 1 & 1.819 \\
\hline Source: Processed secondary data, 2021 &
\end{tabular}

Multiple Regression Equation

This analysis aims to determine whether company value, dividend policy, and capital 
structure affect stock prices. In this study, the technique used is multiple regression analysis, because the independent variable in this study is more than one. The following is a table of data processing results which is the basis for the formation of the research model:

Table 6. Multiple Regression Equation

\begin{tabular}{lccc}
\hline Model & \multicolumn{2}{l}{ Unstandardized Coefficients } & Standardized Coefficients \\
\cline { 2 - 4 } & B & Std. Error & Beta \\
\hline 1 & (Constant) & .039 & .021 \\
& LN_PBV & -.028 & .013 \\
& LN_DPR & .032 & .015 \\
& LN_DER & -.040 & .014 \\
\hline
\end{tabular}

Source: Processed secondary data, 2021

From the statistical processing above, the multiple linear regression equation is obtained as follows:

$$
Y=0.039-0.028 \text { LN_PBV + 0.032 LN_DPR - } 0.040 \text { LN_DER }
$$

The figures resulting from the test are described as follows:

Constant $(\alpha)$

The constant value obtained is 0.039 . This means that if the independent variable (company value (PBV), dividend policy (DPR), and capital structure (DER)) does not exist or is zero, then the share price is 0.039 .

Regression Coefficient ( $\beta$ ) X1

The regression coefficient value of the company value variable (PBV) is -0.028 . This indicates that every one unit increase in company value will decrease the share price by 0.028 . Regression coefficient $(\beta) \times 2$

The regression coefficient value of the dividend policy variable (DPR) is 0.032 . This indicates that each increase of one dividend policy unit will increase the share price by 0.032 . Regression Coefficient $(\beta) \times 3$

The regression coefficient value of the capital structure variable (DER) is -0.040 . This indicates that each increase of one capital structure unit will decrease the share price by 0.040 .

Determination Coefficient Test

The Adjusted R Square value shows 0.169. This indicates that the contribution of the independent variables, namely company value, dividend policy, and capital structure to the dependent variable, namely the stock price is $16.9 \%$, while $83.1 \%$ is determined by other factors outside the research model. The Adjusted $\mathrm{R}$ square value can be seen in the table below:

Table 7. Determination Coefficient Test

\begin{tabular}{lcccc}
\hline Model & $R$ & R Square & Adjusted R Square & Std. Error of the Estimate \\
\hline 1 & $.459 a$ & .211 & .169 & .0910210 \\
\hline \multicolumn{5}{c}{ Source: Processed secondary data, 2021 }
\end{tabular}

Hypothesis Testing (t-test)

This test is conducted to determine how much influence the independent variable has on the dependent variable partially. The benchmark used is to compare the resulting significance value with alpha 0.05 or by comparing t count with $t$ table. After that, look at the $\beta$ value to see the direction of the hypothesis. Based on the results of statistical data processing in the table, it can be seen that the effect of the independent variable on the dependent variable partially is as follows: 
Company value as measured by using PBV does not affect stock prices. It can be seen that the company value variable has a significance value of 0.031 which is smaller than $\alpha 0.05$ or the value of tcount $>t$ table, which is $2.214>1.995$. Judging from $\beta(-0.028)$, it is not following the direction of the hypothesis, which is positive. This shows that the company value variable does not affect stock prices. Thus the first hypothesis $(\mathrm{H} 1)$ is rejected.

Dividend policy as measured by using the DPR has a significant positive effect on stock prices. It can be seen that the dividend policy variable has a significance value of 0.034 which is smaller than $\alpha 0.05$ or the value of tcount> $t$ table, namely $2.171>1.995$. Judging from $\beta(0.032)$, it is following the direction of the hypothesis, which is positive. This shows that the dividend policy variable has a significant positive effect on stock prices. Thus the second hypothesis $(\mathrm{H} 2)$ is accepted.

The capital structure as measured by using DER has a significant negative effect on stock prices. It can be seen that the capital structure variable has a significance value of 0.006 less than $\alpha 0.05$ or the value of tcount> $t$ table, which is $2.861>1.995$. Judging from $\beta(-0.040)$, it is in accordance with the direction of the hypothesis. This shows that the capital structure variable has a significant negative effect on stock prices. Thus the third hypothesis (H3) is accepted.

RESULT AND DISCUSSION

Influence of Company Value (PBV) on Stock Prices

From the results of statistical data analysis it can be seen that the PBV variable shows no effect on stock prices. This indicates that the amount of company value is not fully taken into account by investors in purchasing shares. It can be explained that a larger PBV value indicates that the company is experiencing growth, so investors also think that the company's condition will be favorable for investment. This in turn will increase the company's share price. However, there are contradictory conditions that occur in the PBV ratio, where a PBV ratio that is too high is not what investors want. The main reason is because a high PBV reflects that the price of shares owned by the company is considered too high, so that it is not proportional to the book value of the company or in this case the share price will be overvalued. This contradictory condition causes PBV to have a significant negative effect on stock returns (Faried, 2008). The results of this study support the research of Jumhana (2016) which found that there was no influence between company value and stock prices. This research is not in line with the results of research by Beliana and Budiantara (2015) and Anah, Firdaus and Alliffah (2018) which state that firm value has a positive effect on stock prices.

Influence of Dividend Policy (DPR) on Stock Prices

From the results of statistical data analysis, it can be seen that the Dividend Payout Ratio (DPR) has a significant positive effect on stock prices. This shows that the DPR affects the formation of share prices in manufacturing companies listed on the Indonesia Stock Exchange. The results of this study Sari (2010) that dividend announcements contain information that results in stock price reactions. Dividend distribution gives a positive signal to investors about the prospect of stocks because it indicates the company's ability to generate profits. The statistical results mean that the DPR is one of the factors that must be considered in investing in a company. Because, this study was successful in answering and supporting $\mathrm{H} 2$, namely the size of the DPR had a significant positive effect on stock prices. The results of this study support research conducted by Chaudry, Iqbal and Butt (2015) and Nugraha and Sudaryanto (2016) who found a significant positive effect between dividend policy as measured by the dividend payout ratio and stock prices. However, this research is not in line with the research of Bailia, Tommy \& Baramulli (2016) which states that dividend policy has no effect on stock prices. The effect of dividend policy on stock prices is proxied by the accumulation of abnormal returns in the study of $3.2 \%$ which can be a reference for investors in making decisions. 
Influence of Capital Structure (DER) on Stock Prices

From the results of statistical data analysis, it can be seen that the Debt to Equity Ratio (DER) has a significant negative effect on stock prices. This shows that DER has a signal for investors and affects the formation of share prices in manufacturing companies listed on the Indonesia Stock Exchange. The results of this study are the same as the existing theory which states that investors will react negatively to the high value of the capital structure because high debt is a burden that will be borne from their investment, besides that companies with high debt also have a high risk of liquidation or an inability to pay off everything. obligations because the nature of the investor is risk-averse, which tends to stay away from risk (Tandelilin, 2001). The results of this study support the research of Menon (2016) and anah, Firdaus and Alliffah (2018) which reveal that there is a negative influence between dividend policy and stock prices. This study is not in line with the results of research by Suryawan \& Wirajaya (2017) which states that there is no influence between capital structure on stock prices.

\section{CONCLUSIONS AND SUGGESTION}

Conclusions

Based on this study, this research aims to see to what extent the influence of company value information, dividend policy, and capital structure on stock prices in manufacturing companies listed on the Indonesia Stock Exchange (BEI) in 2008-2010. Based on the research findings and hypothesis testing that has been proposed, it can be concluded that: (1) Company value does not affect stock prices in manufacturing companies listed on the Indonesia Stock Exchange (BEI). (2) Dividend policy has a significant positive effect on stock prices in manufacturing companies listed on the Indonesia Stock Exchange (IDX). (3) Capital structure has a significant negative effect on stock prices in manufacturing companies listed on the Indonesia Stock Exchange (IDX).

Suggestion

For companies, it is better if the decisions taken by managers in implementing the financial management function are decisions that can improve company performance. For investors, it's best to invest in companies that have a good performance by considering various factors. For further research, it can extend the observation period adding to the category of companies used as research samples, for example, all companies listed on the IDX and adding other information as variables that are thought to affect stock prices, such as company performance (financial performance, environmental performance), quality of financial reports, and stock performance as measured by trading volume or bid-ask shares, and using the information on the efficiency of the company conducting research using external factors such as interest rates, inflation rates, currency exchange rates and the political situation as independent variables. 


\section{REFERENCES}

Anah, Sri, Firdaus Iwan \& Alliffah Erna. (2018). Pengaruh Current Ratio, Debt to Equity Ratio dan Price Book Value terhadap Harga Saham pada Sub Sektor Transportasi yang terdaftar di BEl Periode 2012 - 2016. Jurnal Ekonomi.

Aprayuda, R., \& Misra, F. Faktor Yang Mempengaruhi Keinginan Investasi Investor Muda di Pasar Modal Indonesia. E-Jurnal Akuntansi, 30(5), 1084-1098.

Aprayuda, R., Misra, F., \& Kartika, R. (2021). Does the Order of Information Affect Investors' Investment Decisions? Experimental Investigation. Journal of Accounting and Investment, 22(1), 150-172.

Beliani, M. M. I., \& Budiantara, M. (2015). Pengaruh Price Earning Ratio Dan Price To Book Value Terhadap Harga Saham Perusahaan Asuransi Yang Terdaftar Di Bursa Efek Indonesia Tahun 2009-2012. JRA MB, Prodi Akuntansi, Fakultas Ekonomi, UMB Yogyakarta Volume 1 No. 1., Mei 2015, 1(1).

Chaudry, Saima Nasir, Iqbal sajid \& Butt Maheen. (2015). Dividend Policy, Stock Price Volatility \& Firm Size Moderation : Investigation of Bird in Hand Theory in Pakistan.

Darmadji, Tciptono dan H. M. Fakhruddin. (2001). Pasar Modal di Indonesia. Jakarta: Salemba Empat.

Deitiana, Tita. (2011). Pengaruh Rasio Keuangan, Pertumbuhan Penjualan dan Dividen Terhadap Harga Saham. Jurnal Bisnis dan Akuntansi.

Dwipratama, Gede Priana. (2009). Pengaruh PBV, DER, EPS, DPR, dan ROA Terhadap Harga Saham (Studi Empiris Pada Perusahaan Food and Beverage Yang Terdaftar di BEI). Skripsi. Universitas Gunadarma.

Faried, Asbi Rachman. (2008). Analisis Pengaruh Faktor Fundamental Dan Nilai Kapitalisasi Pasar Terhadap Return Saham Perusahaan Manufaktur di BEI. Tesis. Semarang : Universitas diponegoro.

Ghozali, Imam. (2005). Aplikasi Analisis Multivariat dengan Program SPSS. Semarang : Universitas Diponegoro.

Harahap, Syofyan Syafri. (2010). Analisis Kritis Atas Laporan Keuangan. Jakarta: Rajawali Perss.

Hartono, Jogiyanto. (2007). Teori Portofolio dan Analisis Investasi. BPFE: Yogyakarta.

Husni, T., Rahim, R., \& Aprayuda, R. (2020) Cash Compensation, Corporate Governance, Ownership, and Dividend Policy on Banking Performance. Advances in Economics, Business and Management Research, 132, 212-218.

Husnan, Suad. (2003). Manajemen Keuangan Teori dan Aplikasi. Yogyakarta: PT. BPFE.

Januar. (2008). Pengaruh Faktor Fundamental Dan Risiko Sistematis Terhadap Harga Saham Perusahaan Perbankan. Skripsi. Padang : Universitas Negeri Padang.

Jumhana, R Chepi Safei. (2016). Pengaruh PER dan PBV terhadap Harga Saham Perusahaan PT. Lippo Karawaci Tbk. Prosiding Seminar IImiah Nasional.

Kasmir.(2011). Analisis Laporan keuangan. Jakarta: Rajawali Perss.

K.R. Subramanyam dan Jhon J. Wild. (2010). Analisis Laporan Keuangan. Jakarta: Salemba Empat. Luciana, Spica Almilia dan Dwi sulistyowati. (2007). Analisa Terhadap Relevansi Nilai Laba, Arus

Kas Operasi Dan Nilai Buku Ekuitas Pada Periode Di Sekitar Krisis Keuangan Pada Perusahaan Manufaktur di BEJ. Proceeding Seminar Nasional. Jakarta: FE Universitas Trisakti.

Munte, Mei Hotma Mariati. (2009). Pengaruh Faktor Fundamental Terhadap Return Saham Pada Perusahaan Manufaktur Yang Terdaftar di BEl. Tesis. Sumatera : Universitas Sumatera Utara.

Putra, D. G. (2012). Pengaruh Informasi Nilai Perusahaan, Kebijakan Dividen dan Struktur Modal Terhadap Harga Saham (Studi Empiris pada Perusahaan Manufaktur yang Terdaftar di 
Bursa Efek Indonesia) (Doctoral dissertation, Universitas Negeri Padang).

Putra, D. G., \& Rahayu, R. (2020). Peranan Implementasi Tata Kelola Teknologi Informasi (IT Governance) sebagai Faktor Penting dalam Meningkatkan Kinerja Perusahaan. Jurnal Inovasi Pendidikan Ekonomi, 10(1), 01-07.

Putra, D. G., Rahayu, R., \& Putri, A. (2021). The Influence of Enterprise Resource Planning (ERP) Implementation System on Company Performance Mediated by Organizational Capabilities. Journal of Accounting and Investment, 22(2).

Sari, Hestia Permata. (2010). Pengaruh Kebijakan Dividen dan EPS Terhadap Harga Saham. Skripsi. Padang : Universitas Negeri Padang.

Sari, Mega Nurmala. (2011). Pengaruh Laba Akuntansi, Nilai Buku Per Lembar Saham, Arus Kas Operasi, Arus Kas Investasi Dan Arus Kas Pendanaan Terhadap Harga Saham Perusahaan Manufaktur Yang Terdaftar di BEI. Skripsi. Padang : Universitas Negeri Padang.

Sartono, Agus. (2001). Manajemen Keuangan Teori dan Aplikasi. Yogyakarta. BPFE.

Setiawan, Doddy. (2003). Analisis Faktor Fundamental Yang mempengaruhi risiko sistematis sebelum dan selama krisis moneter. Simposium Nasional Akuntansi VI. Surabaya.

Stella. (2009). Pengaruh Price to Earnings Ratio, Debt to Equity Ratio, Return On asset dan Price to Book Value Terhadap Harga Saham. Jurnal Bisnis dan Akuntansi Vol 11 No 2.

Surya, Herman. (2011). Pengaruh faktor likuiditas saham dan faktor fundamental terhadap harga saham. Skripsi. Padang : Universitas Negeri Padang.

Suryawan, I Dewa Gede \& Wirajaya I Gede Ary. (2017). Pengaruh Current Ratio, Debt To Equity Ratio dan Return On Assets pada Harga Saham.

Sofyan, R., Putra, D. G., \& Aprayuda, R. (2020, November). Does the Information on the Internet Media Respond to the Stock Market?. In The Fifth Padang International Conference On Economics Education, Economics, Business and Management, Accounting and Entrepreneurship (PICEEBA-5 2020) (pp. 510-520). Atlantis Press.

Syofyan, R., \& Putra, D. G. (2020, March). The Role of Good Corporate Governance (GCG) Implementation in Indonesian Company. In 4th Padang International Conference on Education, Economics, Business and Accounting (PICEEBA-2 2019) (pp. 819-825). Atlantis Press.

Tandelilin, Eduardus. (2001). Analisis Investasi dan Manajemen Portofolio. Yogyakarta: PT. BPFE.

Wicaksono, Ananto Sarono. (2007). Analisis pengaruh rasio keuangan terhadap harga saham perusahaan yang terdaftar di bursa efek Jakarta. Skripsi. Semarang: Universitas Negeri Semarang.

Yulita, Ira. (2011). Pengaruh Laba Akuntansi, Laba per Lembar Saham, Dividend Payout Ratio $b$ Terhadap Harga Saham. Skripsi. Padang : Universitas Negeri Padang 